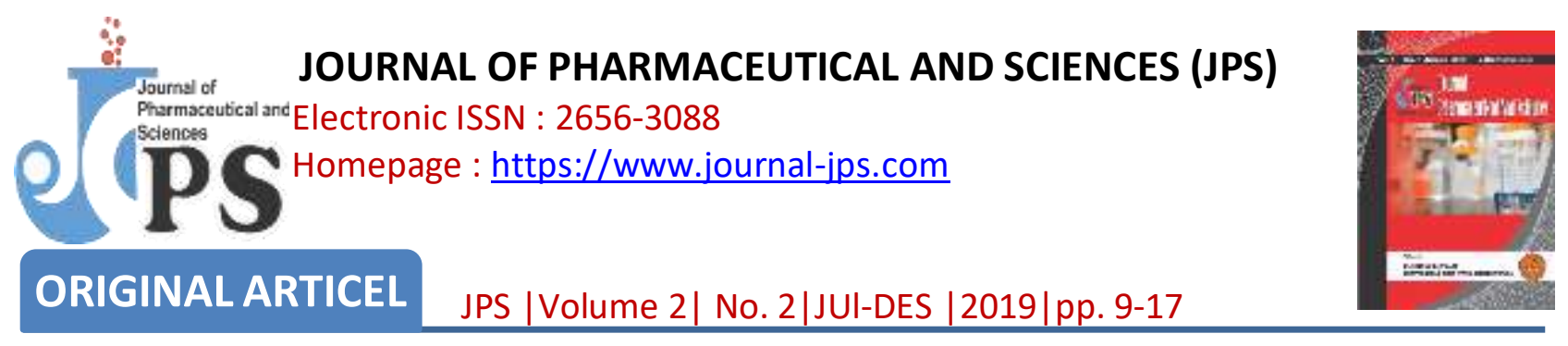

\title{
APHRODISIAC EFFECTIVENESS TEST ETHANOL EXTRACT ALBEDO (MESOCARP) MELON (Cucumis melo L.) ON MICE (Mus musculus)
}

\section{UJI EFEKTIVITAS AFRODISIAKA EKSTRAK ETANOL ALBEDO (MESOCARP) MELON (Cucumis melo L.) PADA MENCIT (Mus musculus)}

\author{
Muhammad Gunawan ${ }^{1}$, Nolani Nurlita Bengi ${ }^{1}$ \\ Program Studi Farmasi, Fakultas Farmasi, Universitas Tjut Nyak Dhien Medan, \\ Jl. Gatot Subroto / Jl. Rasmi No. 28 Medan 20123 \\ Email: Muhammadgunawan905@gmail.com
}

\begin{abstract}
Decreased sexual desire is one of the factors of disharmony in the marital relationship and quite disturbing in domestic life, Medicine is traditionally widely taken, one using plants containing aphrodisiac. Aphrodisiac a kind of aphrodisiac to increase sex drive. In general, the plant compound that has potential as aphrodisiac is citrulline. Melon (Cucumis melo L.) is a plant that contains citrulline, which is used in the coating of white / albedo (mesocarp). This study aims to determine the melon fruit mesocarp have afrodisiaka effect on the effective dose. This study is an experimental method is percolation extraction using 30 mice were divided into 5 groups. Group I (CMC 0.5\%), group II (herbal pegs the earth), Group III, IV, and V respectively using albedo Ethanol Extract Melon (EEAM) doses of 9, 18 and $36 \mathrm{~g} / \mathrm{kg}$. Oral administration by introducing watching, climbing and coitus. Observations were made for 5 days in a row. Statistical testing using test methods Post-Hoc Duncan SPSS 24.0. Statistical analysis showed no significant differences between the test group with $a>0.05$ and an effective dose of $18 \mathrm{~g} / \mathrm{kg}$.
\end{abstract}

Keywords : Albedo Melon; Aphrodisiac; Pasak Bumi herbal medicine; Post-Hoct Duncan

\begin{abstract}
ABSTRAK
Penurunan hasrat seksual merupakan salah satu faktor ketidakharmonisan dalam hubungan suami istri dan cukup meresahkan dalam kehidupan rumah tangga. Pengobatan secara tradisional banyak ditempuh, salah satunya dengan menggunakan tumbuhan yang mengandung afrodisiaka. Afrodisiaka merupakan semacam zat perangsang yang dapat meningkatkan gairah seks. Secara umum senyawa tanaman yang berpotensi sebagai afrodisiaka adalah sitrulin. Buah melon (Cucumis melo L.) merupakan salah satu tanaman yang mengandung sitrulin, dimana yang digunakan adalah pada bagian lapisan putih/albedo (mesocarp). Penelitian ini bertujuan untuk mengetahui mesocarp buah melon memiliki efek afrodisiaka pada dosis yang efektif.
\end{abstract}


Penelitian ini merupakan penelitian eksperimental dengan metode ekstraksi secara perkolasi menggunakan 30 ekor mencit dan dibagi menjadi 5 kelompok. Kelompok I (CMC 0,5\%), kelompok II (jamu pasak bumi), kelompok III, IV, dan V secara berturut-turut menggunakan Ekstrak Etanol Albedo Melon (EEAM) dosis 9, 18, dan $36 \mathrm{~g} / \mathrm{kgBB}$. Pemberian secara oral dengan mengamati introducing, climbing dan coitus. Pengamatan dilakukan selama 5 hari berturut-turut. Pengujian statistik menggunakan metode uji Post-Hoc Duncan SPSS 24.0. Hasil uji statistik menunjukkan tidak ada perbedaan yang signifikan antar kelompok uji dengan $a>0,05$ dan dosis efektif sebesar $18 \mathrm{~g} / \mathrm{kgBB}$.

Kata kunci: Albedo Melon; Afrodisiaka; Jamu Pasak Bumi; Post-Hoct Duncan.

\section{PENDAHULUAN}

Gairah seks merupakan sesuatu kebutuhan alamiah yang ada dari dalam tubuh manusia yang dibutuhkan untuk mencapai kepuasan dalam kehidupan seks yang indah dan harmonis. Penurunan hasrat seksual merupakan salah satu faktor ketidakharmonisan dalam hubungan suami istri. Masalah gangguan seksual merupakan masalah yang cukup meresahkan dalam kehidupan rumah tangga (Yakubu, et al, 2007).

Pengobatan tradisional selalu menjadi pilihan pengobatan utama, karena memiliki efek samping lebih rendah dan harga yang relatif lebih murah. $\mathrm{Hal}$ ini, yang mendorong penggunaan afrodisiaka sebagai alternatif pengobatan semakin diminati, terlebih afrodisiaka merupakan obat tradisional yang berasal dari bahan-bahan alami seperti tumbuhan (Gendrowati, 2014).

Afrodisiaka adalah bahan organik, minyak esensial (minyak atsiri), obat, minuman herbal atau bahan yang dapat membangkitkan gairah seksual. Afrodisiaka merupakan semacam zat perangsang yang dapat meningkatkan gairah seks (Oktavina, 2006). Beberapa penelitian menunjukkan bahwa tumbuhan afrodisiaka mengandung senyawa sitrulin yang berfungsi meningkatkan asam nitrat di dalam tubuh. Asam sitrat akan membantu mengirimkan oksigen lewat peredaran darah keseluruh tubuh. Efek meningkatkan sirkulasi darah ini terjadi juga pada genital pria (Hidayat, 2012).

Salah satu tanaman yang mengandung sitrulin adalah buah melon. Buah melon hanya dikonsumsi pada bagian daging yang wama mencolok (misalnya orange, hijau) sedangkan pada bagian lapisan putih yang disebut albedo (mesocarp) kurang diminati masyarakat untuk dikonsumsi dan hanya dibuang menjadi limbah yang tidak dimanfaatkan (Akanji, 2014).
Berdasarkan uraian tersebut maka dilakukan penelitian terhadap albedo (mesocarp) buah melon terhadap aktivitas seksual pada mencit dengan mengamati 3 parameter yaitu introducing, climbing dan coitus (ICC) (Harmusyanto, 2013).

\section{METODE PENELITIAN}

\section{Bahan dan Alat}

Bahan-bahan yang digunakan pada penelitian yaitu albedo (mesocarp) melon, carboxy methyl cellulose (CMC), akuades (Brataco, Indonesia), etanol 70\% (Brataco, Indonesia), dan jamu pasak bumi.

Alat-alat yang digunakan berupa alat-alat gelas, perkolator, blender (Miyako ${ }^{\circledR}$ ), alumunium foil, blender, freeze dryer (Modulio), gunting, kandang mencit, kaca arloji, kertas perkamen, kertas saring, lemari pengering, lumpang, neraca analitik (Ohaus $\left.{ }^{\circledR}\right)$, neraca hewan (Presica Geniweigher $1500^{\circledR}$ ), oral sonde, rotary evaporator $\left(\right.$ Buchi $\left.^{\circledR}\right)$, stamper, stopwatch dan spuit $1 \mathrm{ml}$.

\section{Penyiapan Sampel}

Buah melon yang diperoleh dibersihkan dari kotoran, dipisahkan daging buah dengan kulitnya, kemudian bagian albedo (mesocarp) diiris tipistipis, dikeringkan di dalam lemari pengering dengan suhu $\pm 40^{\circ} \mathrm{C}$ sampai albedo (mesocarp) kering, kemudian dihaluskan serta ditimbang berat serbuk keringnya. Serbuk simplisia disimpan dalam wadah tertutup baik.

\section{Ekstraksi Sampel}

Sebanyak $500 \mathrm{~g}$ serbuk simplisia albedo (mesocarp) melon dimaserasi dengan etanol $70 \%$ selama 3 jam. Selanjutnya diperkolasi dengan kecepatan 20 tetes per menit. Perkolasi dihentikan jika perkolat yang dihasilkan menjadi bening. Selanjutnya perkolat yang diperoleh disuling 
dengan tekanan tinggi pada suhu tidak lebih dari $50^{\circ} \mathrm{C}$ menggunakan rotary evaporator sehingga diperoleh ekstrak kental, kemudian ekstrak dikeringkan dengan cara pengering beku menggunakan freeze dryer dan diperoleh ekstrak kering dari albedo (mesocarp) melon, ditimbang dan disimpan dalam wadah kaca bertutup baik, selanjutnya disebut Ekstrak Etanol Albedo (Mesocarp) Melon (EEAMM) (Depkes RI. 2000).

\section{Pembuatan Larutan Uji}

a. Suspensi CMC 0,5\% (Kontrol Negatif) Sebanyak $1 \mathrm{~g} \mathrm{CMC} \mathrm{(carboxy} \mathrm{methyl} \mathrm{cellulose)}$ ditaburkan ke dalam lumpang yang telah berisi akuades panas sebanyak $70 \mathrm{ml}$, biarkan selama 15 menit sehingga diperoleh massa yang transparan, setelah mengembang digerus lalu diencerkan dengan sedikit akuades. Kemudian dimasukkan ke dalam wadah, dicukupkan dengan akuades hingga $200 \mathrm{ml}$

b. Suspensi Jamu Pasak Bumi (Kontrol Positif)

Sebanyak $6 \mathrm{~g}$ jamu pasak bumi dilarutkan dengan CMC hingga $50 \mathrm{ml}$ (12\%). Pemberian suspensi jamu pasak bumi disesuaikan dengan berat badan mencit (faktor pengali untuk mencit $20 \mathrm{~g}=0,13 \mathrm{ml}$ ).

\section{c. Suspensi EEAMM Dosis $9 \mathrm{~g} / \mathrm{kgBB}$}

Ditimbang sebanyak $179 \mathrm{mg}$ EEAMM, disuspensikan dalam CMC 0,5\% sampai 10 $\mathrm{ml}$ sampai homogen.

\section{d. Suspensi EEAMM Dosis $18 \mathrm{~g} / \mathrm{kg} \mathrm{BB}$}

Ditimbang sebanyak $358,8 \mathrm{mg}$ EEAMM, disuspensikan dalam CMC 0,5\% sampai 10 $\mathrm{ml}$ sampai homogen.

\section{e. Suspensi EEAMM Dosis $36 \mathrm{~g} / \mathrm{kg}$ BB}

Ditimbang sebanyak $717,6 \mathrm{mg}$ EEAMM, disuspensikan dalam CMC 0,5\% sampai 10 $\mathrm{ml}$ sampai homogen.
Penyiapan Hewan Percobaan

Hewan percobaan yang digunakan adalah mencit jantan dan betina (Mus musculus) yang sehat dengan berat badan 20-30 g, berumur 2-3 bulan sebanyak 30 ekor. Mencit dibagi secara acak menjadi 5 kelompok, masing-masing kelompok terdiri dari 3 ekor mencit jantan dan 3 ekor mencit betina. Tiap hewan percobaan diaklimatisasi ditempat penelitian selama 7 hari diberi pakan dan minum ad libitum (Andri, 2007).

\section{Parameter pengamatan efek afrodisiaka}

Pengamatan dilakukan selama 2 jam setiap hari selama 5 hari berturut-turut. Parameter yang diamati adalah:

1. Introducing yaitu interval waktu dari perkenalan pada hewan betina sampai tunggangan pertama oleh hewan jantan.

2. Climbing yaitu jumlah tunggangan yang dilakukan oleh mencit jantan sebelum ejakulasi dalam waktu 2 jam setelah pemberian sediaan, selama 5 hari.

3. Coitusyaitu interval waktu selama sekali tunggangan yang dilakukan oleh mencit jantan (Indrisari, dkk, 2013).

\section{Analisis Data}

Data dari hasil penelitian ini dianalisa secara statistik dengan ANOVA pada tingkat kepercayaan $95 \%$. Data ini dianalisa dengan menggunakan software statistik SPSS 24.0 metode Post-Hoc Duncan.

\section{HASIL DAN DISKUSI}

Uji makroskopik berupa uji organoleptis terhadap albedo (mesocarp) melon segar dan simplisia albedo (mesocarp) melon. Buah melon berbentuk bulat, albedo (mesocarp)-nya berwama hijau muda, tidak berasa dan tidak berbau. Serbuk simplisia albedo (mesocarp) melon berwarna hijau kecoklatan, tidak berasa dan memiliki aroma khas. Gambar tanaman dan simplisia dapat dilihat pada Gambar 1. 

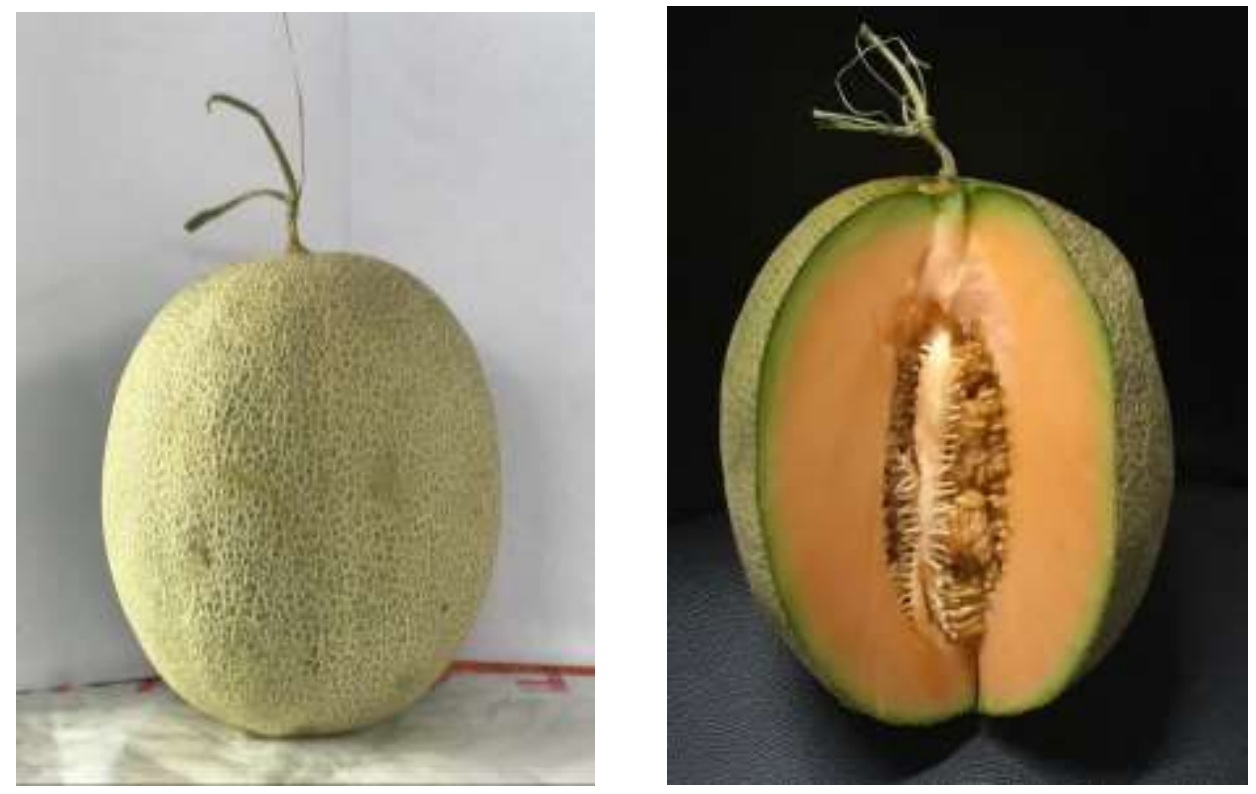

A. Buah Melon (Cucumis melo L.)

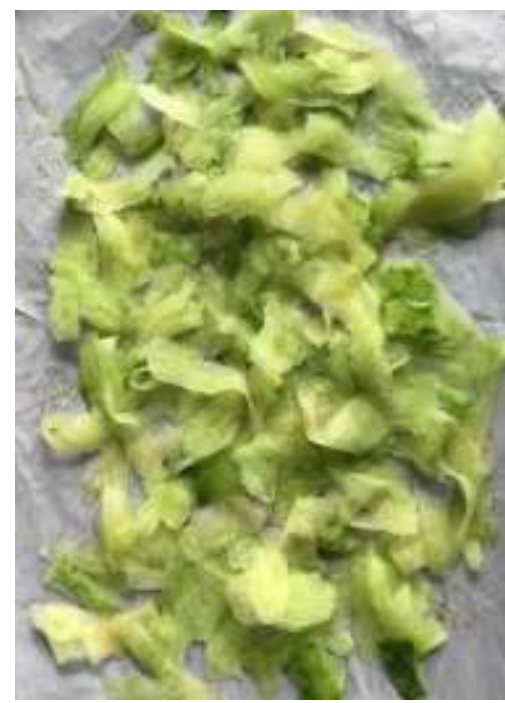

B. Albedo (mesocarp) segar

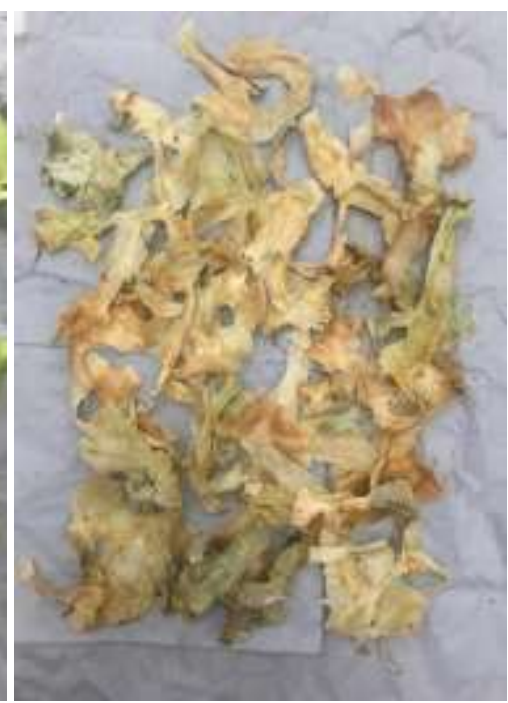

C. Simplisia albedo

(mesocarp)

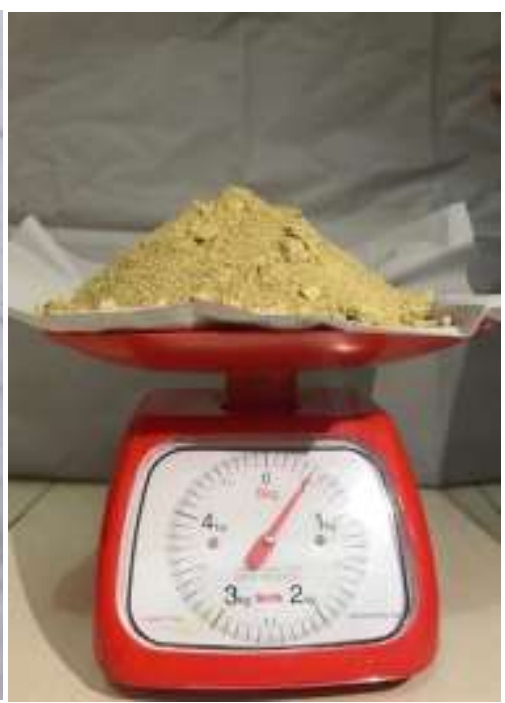

D. Serbuk simplisia albedo (mesocarp)

Gambar 1. Buah Melon dan Simplisia Albedo (Mesocarp) Melon

Pembuatan ekstrak dari $8 \mathrm{~kg}$ albedo (mesocarp) melon segar diperoleh simplisia seberat 700 gram. Sebanyak 500 gram serbuk simplisia albedo (mesocarp) melon di perkolasi dengan etanol $70 \%$ dan diperoleh ekstrak seberat 230 gram. Pada penetapan kadar air yang dilakukan dengan metode Analisa thermogravimetri. Hasil penetapan kadar air simplisia albedo (mesocarp) melon sebesar 9,2\%. Syarat persentase kadar air dalam simplisia adalah $<10 \%$. Hasil uji efek afrodisiaka ekstrak etanol albedo (mesocarp) melon pada parameter introducing dari setiap kelompok menunjukkan bahwa kelompok IV memiliki memiliki aktivitas introducing yang paling baik dibandingkan kelompok lainnya, tetapi tidak melebihi kelompok II (kontrol positif). Hal ini tidak berbeda dengan hasil penelitian Arnida (2018), yang menunjukkan bahwa pemberian ekstrak akar cawat hanoman pada mencit sebagai afrodisiaka yang menunjukkan aktivitas introducing pada mencit meningkat pada kelompok IV (dosis II) yang dapat dilihat pada Tabel 1 dan Gambar 2. 
Tabel 1. Hasil pengamatan introducing hewan uji

\begin{tabular}{|l|c|c|c|c|c|c|}
\hline \multicolumn{1}{c}{ Kelompok Uji } & \multicolumn{9}{c}{ Hari ke- } & Rata-rata \\
\hline & $\mathbf{1}$ & $\mathbf{2}$ & $\mathbf{3}$ & $\mathbf{4}$ & $\mathbf{5}$ & \\
\hline Kell (CMC) & 7 & 9 & 9 & 8 & 9,3 & 9 \\
\hline Kel II (Jamu Pasak Bumi) & 18 & 21 & 24 & 27 & 31 & 24,3 \\
\hline Kel III (Dosis I) & 10 & 12 & 14 & 15,7 & 17,3 & 13,9 \\
\hline Kel IV (Dosis II) & 16 & 19 & 21 & 22 & 25 & 20,5 \\
\hline KelV (Dosis III) & 12 & 16 & 17 & 21 & 23 & 17,9 \\
\hline
\end{tabular}

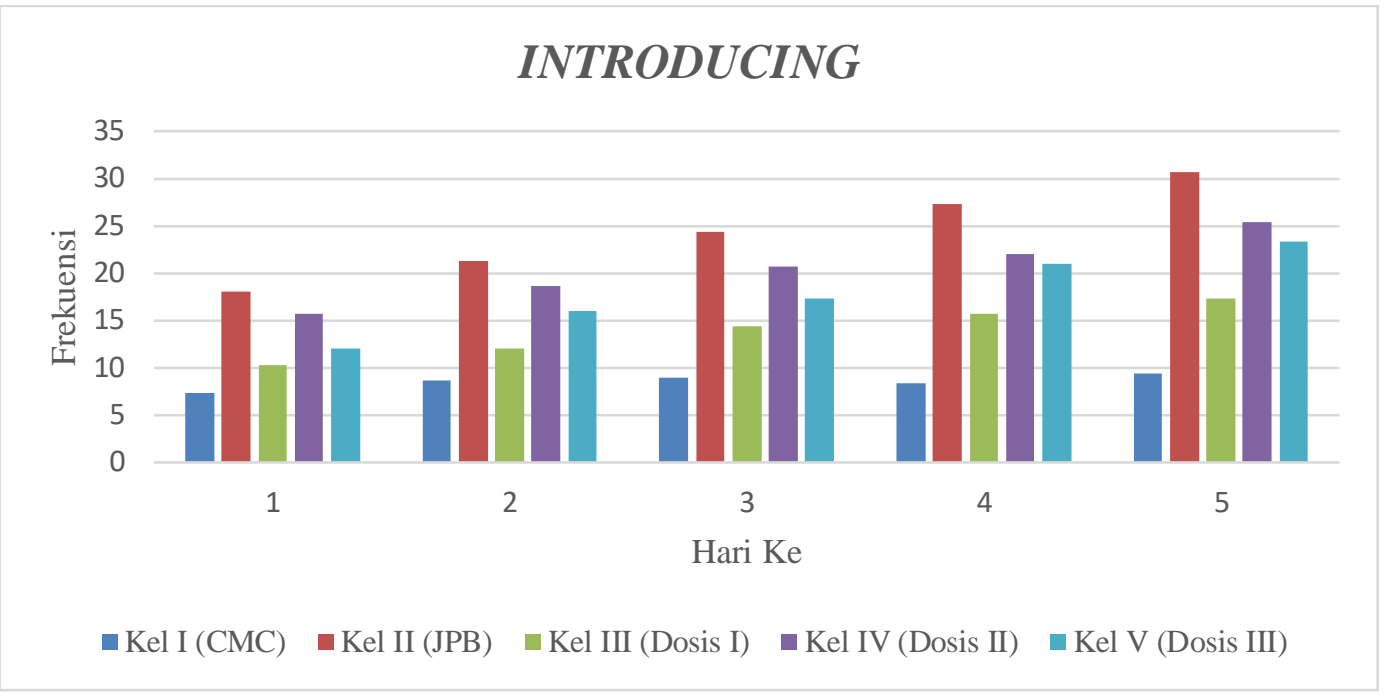

Gambar 2. Grafik hasil pengamatan introducing pada mencit

Pada parameter climbing menunjukkan bahwa kelompok II, III, IV dan V terjadi aktivitas climbing tertinggi pada hari ke-5. Menurut penelitian Prita (2010), waktu introducing yang relatif lama dapat meningkatkan libido atau hasrat seksual seseorang sehingga dengan meningkatnya libido maka akan timbul dorongan seksual yang kuat. Sehingga hal tersebut mempengaruhi frekuensi aktivitas climbing pada mencit. Hasil dan grafik dapat dilihat pada Tabel 2 dan Gambar 3.

Tabel 2. Hasil pengamatan climbing hewan uji

\begin{tabular}{|l|c|c|c|c|c|c|}
\multicolumn{1}{c}{ Kelompok Uji } & $\mathbf{1}$ & $\mathbf{2}$ & $\mathbf{3}$ & $\mathbf{4}$ & $\mathbf{5}$ & Rata-rata \\
\hline Kel I (CMC) & 4 & $\mathbf{5}$ & $\mathbf{5}$ & 6 & 6 & 5 \\
\hline Kel II (Jamu Pasak Bumi) & 16 & 26 & 36 & 40 & 45 & 32 \\
\hline Kel III (Dosis I) & 9 & 15 & 25 & 28 & 31 & 22 \\
\hline Kel IV (Dosis II) & 14 & 21 & 33 & 36 & 40 & 29 \\
\hline Kel V (Dosis III) & 12 & 21 & 29 & 32 & 35 & 26 \\
\hline
\end{tabular}




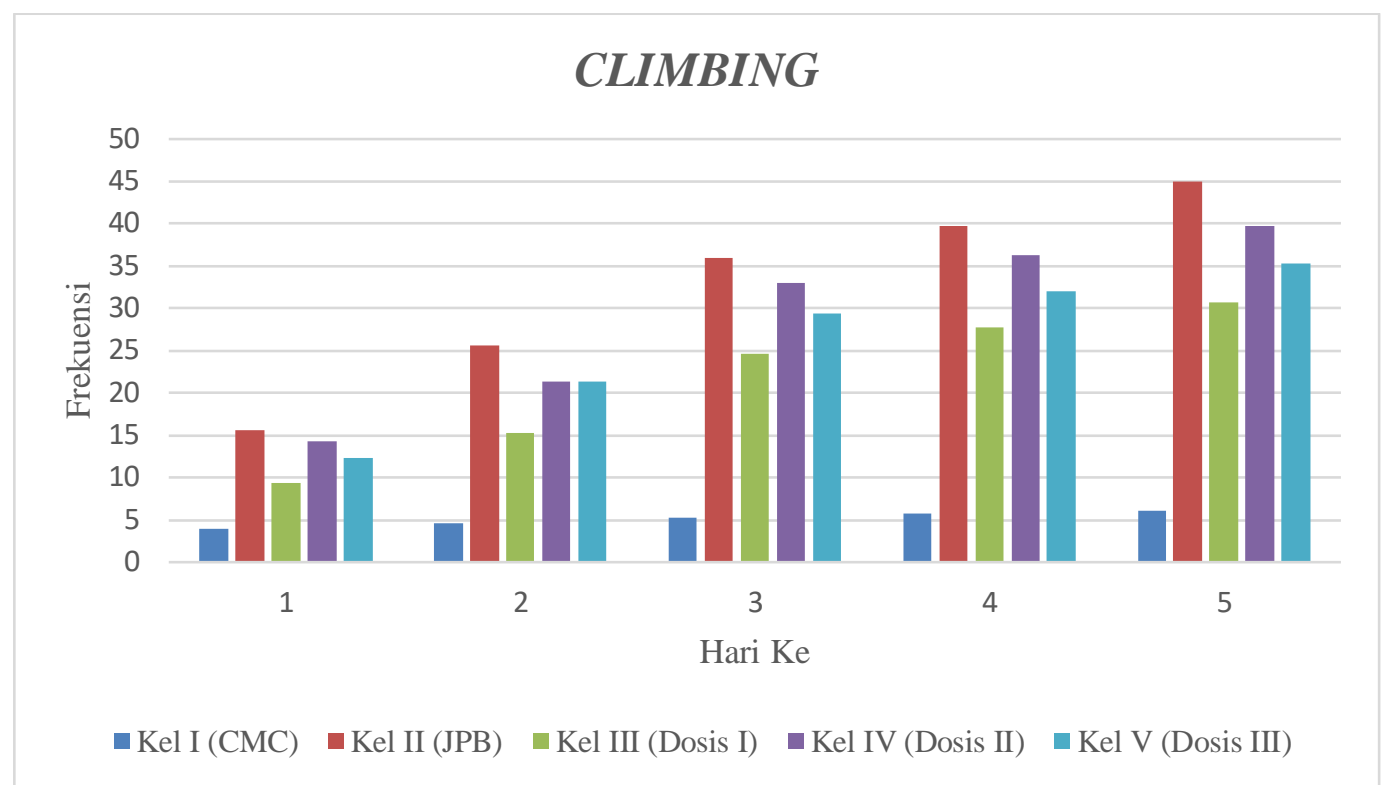

Gambar 3. Grafik hasil pengamatan climbing pada mencit

Pada parameter coitus menunjukkan bahwa kelompok II, III, IV dan V terjadi aktivitas coitus tertinggi pada hari ke-5 yang dapat dilihat pada Tabel 3 dan Gambar 4. Hal ini kemungkinan disebabkan karena ketersediaan zat aktif (saponin, flavonoid dan alkaloid) berada lebih banyak dari pada pemberian hari sebelumnya. Hal ini sesuai dengan penelitian Nugroho (2005), yang mengatakan bahwa umumnya tanaman yang berpotensi sebagai afrodisiaka yaitu senyawa turunan saponin dan flavonoid.

Dari parameter uji ICC (Introducing, Climbing, Coitus) terlihat bahwa kelompok II memiliki perbedaan terhadap lainnya. Namun, pada kelompok IV tidak terlihat perbedaan yang jauh terhadap kelompok II. Hal ini disebabkan kelompok IV memang memiliki efek afrodisiaka hampir sama dengan kelompok II, dibandingkan dengan kelompok I, III dan IV.

Berdasarkan parameter ICC dosis EEAMM kelompok IV memiliki efek afrodisiaka yang paling efektif karena mempunyai hasil yang tidak berbeda jauh dengan kelompok II (Jamu Pasak Bumi).

Tabel 3. Hasil pengamatan coitus hewan uji

\begin{tabular}{|l|c|c|c|c|c|c|}
\multicolumn{1}{c}{ Kelompok Uji } & \multicolumn{9}{c}{ Hari ke- } & Rata-rata \\
\hline Kel I (CMC) & $\mathbf{2}$ & $\mathbf{3}$ & $\mathbf{4}$ & $\mathbf{5}$ & \\
\hline Kel II (Jamu Pasak Bumi) & 1 & 2 & 4 & 5 & 6 & 4 \\
\hline Kel III (Dosis I) & 0 & 0 & 1 & 1 & 2 & 1 \\
\hline Kel IV (Dosis II) & 0 & 1 & 2 & 3 & 5 & 2 \\
\hline Kel V (Dosis III) & 0 & 1 & 1 & 2 & 3 & 1 \\
\hline
\end{tabular}




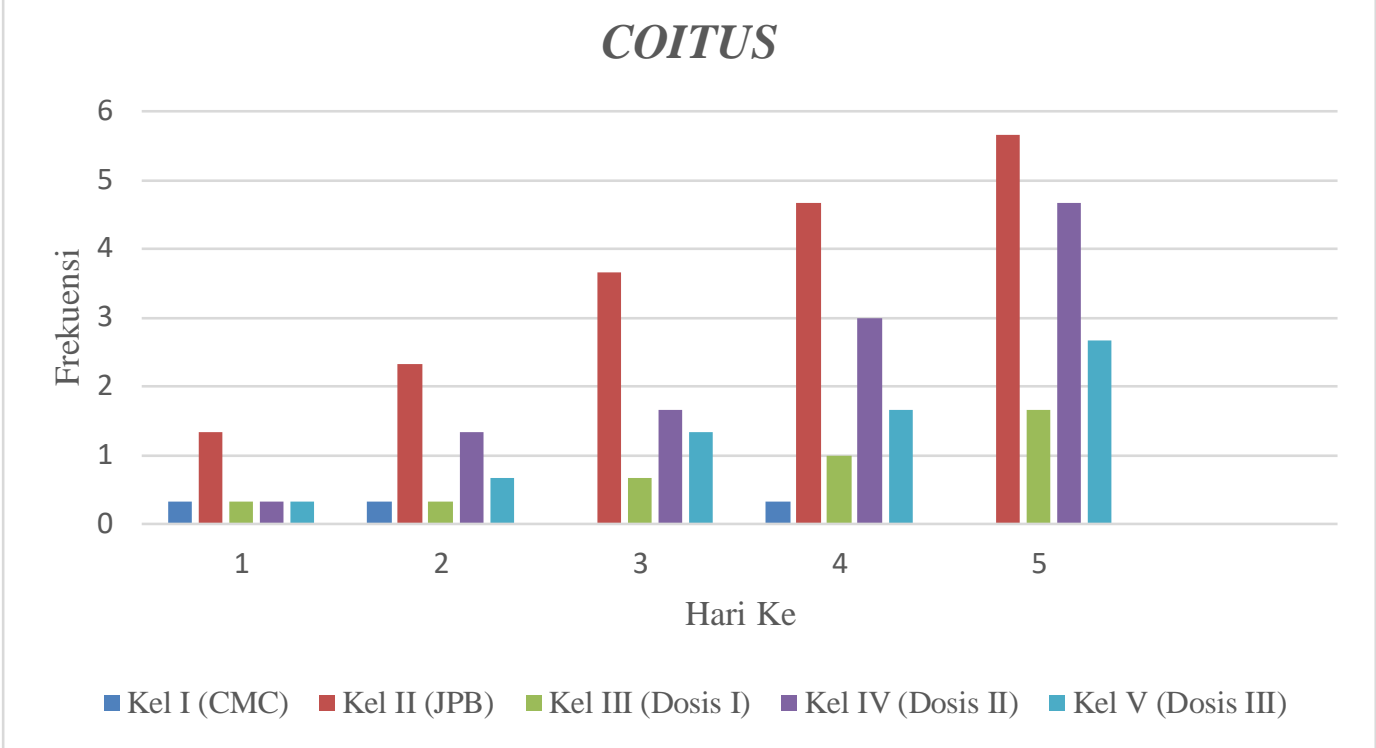

Gambar 4. Grafik hasil pengamatan coitus pada mencit

Berdasarkan perhitungan data introducing, climbing dan coitus pada hari ke-5 dengan menggunakan SPSS metode Post-Hoc Duncan, maka hasilnya dapat dilihat pada Tabel 4,5 , dan 6. Pada parameter introducing terdapat perbedaan nyata efek afrodisiaka pada mencit antara kelompok CMC terhadap semua perlakuan. Dosis I berbeda nyata terhadap semua perlakuan. Dosis II dan III berbeda nyata terhadap CMC, dosis I dan jamu pasak bumi. Jamu pasak bumi berbeda nyata terhadap semua perlakuan. Pada parameter climbing terdapat perbedaan nyata efek afrodisiaka pada mencit antara semua kelompok perlakuan, sedangkan pada parameter coitus terdapat perbedaan nyata efek afrodisiaka pada mencit antara kelompok CMC terhadap semua perlakuan. Dosis I dan III berbeda nyata terhadap CMC, dosis Il dan jamu pasak bumi.

Tabel 4. Hasil uji beda rata-rata Post-Hoc Duncan terhadap efek afrodisiaka pada mencit dengan pengamatan introducing pada hari ke-5

\section{Hari Ke 5}

Duncana

\begin{tabular}{lccccc}
\hline \multirow{2}{*}{ Perlakuan } & N & \multicolumn{4}{c}{ Subset for alpha $=0.05$} \\
\cline { 3 - 6 } & & 1 & 2 & 3 & 4 \\
\hline CMC & 3 & 9,3333 & & & \\
Dosis I & 3 & & 17,3333 & & \\
Dosis III & 3 & & & 23,3333 & \\
Dosis II & 3 & & & 25,3333 & \\
Jamu Pasak Bumi & 3 & & & & 30,6667 \\
\hline Sig. & & 1,000 & 1,000 &, 330 & 1,000 \\
\hline
\end{tabular}


Tabel 5. Hasil uji beda rata-rata Post-Hoc Duncan terhadap efek afrodisiaka pada mencit dengan pengamatan climbing pada hari ke-5

\section{Hari Ke 5}

Duncan ${ }^{a}$

\begin{tabular}{lcccccc}
\hline \multirow{2}{*}{ Perlakuan } & \multirow{2}{*}{$\mathrm{N}$} & \multicolumn{5}{c}{ Subset for alpha $=0.05$} \\
\cline { 3 - 6 } & & 1 & 2 & 3 & 4 & 5 \\
\hline CMC & 3 & 8,3333 & & & & \\
Dosis I & 3 & & 30,6667 & & & \\
Dosis III & 3 & & & 35,3333 & & \\
Dosis II & 3 & & & & 39,6667 & \\
Jamu Pasak Bumi & 3 & & & & & 45,0000 \\
\hline Sig. & & 1,000 & 1,000 & 1,000 & 1,000 & 1,000 \\
\hline
\end{tabular}

Tabel 6. Hasil uji beda rata-rata Post-Hoc Duncan terhadap efek afrodisiaka pada mencit dengan pengamatan coitus pada hari ke-5.

\section{Hari Ke 5}

Duncana

\begin{tabular}{|c|c|c|c|c|}
\hline \multirow{2}{*}{ Perlakuan } & \multirow{2}{*}{$\mathrm{N}$} & \multicolumn{3}{|c|}{ Subset for alpha $=0.05$} \\
\hline & & 1 & 2 & 3 \\
\hline$\overline{\mathrm{CMC}}$ & 3 &, 0000 & & \\
\hline Dosis I & 3 & & 1,6667 & \\
\hline Dosis III & 3 & & 2,6667 & \\
\hline Dosis II & 3 & & & 4,6667 \\
\hline Jamu Pasak Bumi & 3 & & & 5,6667 \\
\hline Sig. & & 1,000 & 165 & , 165 \\
\hline
\end{tabular}

\section{KESIMPULAN}

Berdasarkan pengamatan selama penelitian dan pembahasan, maka dapat disimpulkan bahwa Ekstrak etanol albedo (mesocarp) melon (Cucumis melo L.) memiliki efektivitas afrodisiaka pada mencit (Mus musculus), dan pada dosis $18 \mathrm{~g} / \mathrm{kgBB}$ paling efektif terhadap efek afrodisiaka pada mencit (Mus musculus)

\section{UCAPAN TERIMA KASIH}

Penulis mengucapkan terima kasih yang sebanyak-banyaknya kepada segenap keluarga besar Program Studi Farmasi Fakultas Farmasi UTND, Bapak dan lbu Dosen, para staff dan karyawan, serta mahasiswa-mahasiswi Program Studi Farmasi UTND.

\section{REFERENSI}

Akanji, M. A dan Oladiji, A. T. 2005. Aphrodisiac Potentials of Aqueous Extract of Fadogia Agrestis Stem in Male Albino Rats. Asian J Andrology. 7: 399-404.

Andri, W. Y. 2010. Produksi Mencit Putih (Mus musculus) dengan Substitusi Bawang Putih (Allium sativum) dalam Ransum. Skripsi. Bogor: Fakultas Peternakan Institut Pertanian Bogor. Halaman 3-5.

Arnida. 2018. Uji Aktivitas Afrodisiaka Ekstrak Metanol Akar Tumbuhan Cawat Hanoman (Labisia pumila) terhadap Mencit Putih Jantan (Mus musculus L) Galur BALB/C. Makalah Seminar IImiah. Banjarbaru: Universitas Lambung Mangkurat. Halaman 7. 
Depkes RI. 2010. Farmakope Herbal Indonesia. Jakarta: Depkes RI. Halaman 113-115.

Gendrowati, F. 2014. TOGA: Tanaman Obat Keluarga. Jakarta: Padi. Halaman 17.

Harmusyanto, R. 2013. Studi Mengenai Efek Daun

Katuk (Sauropus Androgynus (L) Merr.)Terhadap Libido Kelinci Jantan (Oryctolagus Cuniculus) Sebagai Afrodisiak. Jurnal Fakultas Farmasi Universitas Surabaya. 2(1): 5-6.

Hidayat, A. 2012. Kebutuhan Dasar Manusia. Surabaya: Health Books Publishing. Halaman 6-7.

Indrisari, M., Rahimah, St.,Umar, A. H dan Allyah, A. P. 2013. Uji Efek Afrodisiaka dari Ekstrak Bawang Putih (Alliumsativum) pada Hewan Coba Mencit (Mus musculus). Jurnal Farmasi Akademi Farmasi Kebangsaan Sekolah Tinggi IImu Farmasi. 2: 140-144.
Nugroho. 2005. Toksisitas Akut dan Khasiat Ekstrak Som Jawa (Talinum paniculatum Gaertn.) sebagai Stimulan. Jurnal IImu Kefarmasian Indonesia. 3(1): 17-20.

Oktavina, D.M. 2006. Ramuan Afrodisiak Nusantara Pembangkit Gairah. Jakarta: Esensi. Halaman 76.

Prita, D. 2010. Uji Afrodisiaka Infusa Kuncup Bunga Cengkeh (Syrgyzum aromaticum) terhadap Libido Tikus Jantan. Skripsi. Surakarta: Universitas Muhammadiyah Surakarta. Halaman 32.

Yakubu, M. T., Akanji, M. A dan Oladiji, A. T. 2007. Male Sexual Dysfunction and Methods Used In Assesing Medicinal Plants With Aphrodisiac Potentials: Pharmacognosy Reviews. 1: 49-56. 